\title{
Activation of the hedgehog pathway in chronic myelogeneous leukemia patients
}

\author{
Bing Long, Huanling Zhu*, Cuixia Zhu, Ting Liu, Wentong Meng
}

\begin{abstract}
Background: Hedgehog $(\mathrm{Hh})$ signaling pathway is involved in regulation of many tissues development and oncogenesis. Recently, Hh signaling has been identified as a required functional pathway for leukemia stem cells (LSCS), and loss of this pathway impairs leukemia progression.

Objectives: The aim of this study was to determine the expression of Hedgehog signaling molecules in Chronic Myelogeneous Leukemia (CML) patients and normal people by semiquantitative polymerase chain reaction (PCR) and to correlate mRNA expression to patients' clinical data.

Results: Here, we showed that Sonic hedgehog (Shh), Smoothened (Smo), and Gli1 genes of Hh signaling were significantly upregulated in CML patients when compared with normal people ( $P<0.001)$. The levels of Shh, Smo mRNA in chronic phase of CML patients were obviously lower than that in blast crisis $(p<0.05)$. There were no significant differences of Shh, Ptch1, Smo, Gli1 mRNA expression found when comparing CML patients of chronic phase (CP) with imatinib(IM) treated or not( $p>0.05)$.

Conclusions: These findings suggested that activation of the Hh pathway maybe associated with CML progression. Treatment of CML with imatinib, a selective inhibitor of the BCR-ABL tyrosine kinase inhibitor, has no significant influence on the inhibition of Hh pathway of CML-CP patients.
\end{abstract}

\section{Introduction}

Chronic myelogeneous leukemia (CML) is a clonal disease that originates from a single transformed hematopoietic stem cell (HSC) or multipotent progenitor cell harboring a chromosomal translocation between chromosome 9 and 22 [t(9;22)(q34; 111$)]$, resulting in the formation of Philadelphia(Ph) chromosome and at the molecular level, a chimeric gene known as BCR-ABL responsible for CML initiation. CML often initiates in a chronic phase, and without intervention, eventually progresses to a terminal blastic phase. The introduction of imatinib mesylate, has revolutionized the disease management. However, imatinib does not cure CML, and one of the reasons is that imatinib does not kill leukemia stem cells (LSCs) in CML $[1,2]$. Recent studies suggest that developmental pathway like Hedgehog signaling pathway played a role during the expansion of BCR-ABL-positive leukemic stem cells [3,4]. Hedgehog

\footnotetext{
* Correspondence: zhuhuanling@medmail.com.cn
Department of hematology, West China Hospital, Sichuan University. Key lab

* Correspondence: zhuhuanling@medmail.com.cn of Hematology of Sichuan Province. 37 Guoxue xiang St. Chengdu, Sichuan, 610041, China
}

(c) 2011 Long et al; licensee BioMed Central Ltd. This is an Open Access article distributed under the terms of the Creative Commons Attribution License (http://creativecommons.org/licenses/by/2.0), which permits unrestricted use, distribution, and reproduction in any medium, provided the original work is properly cited. ligands (Sonic hedgehog [Shh], Indian hedgehog [Ihh], and Desert hedgehog [Dhh]) produced by stroma cells bind to the seven-transmembrane domain receptor Patched (Ptch), thereby alleviating patched-mediated suppression of smoothened (Smo), a putative seventransmembrane protein. This results in a conformational change of Smo and subsequent activation of the pathway, leading to induction of the Gli transcription factors and transcription of target genes like Ptch1, cyclin D1, and Bcl2 [5-7]. This study shows the expression and significance of Hh signaling pathway target genes Shh, Ptch1, Smo and Gli1 in patients with CML.

\section{Materials and methods \\ Samples}

Sixty cases of CML treated at West China Hospital of Sichuan University were included in this study from May 2009 to January 2010. The diagnosis of CML was established on the basis of WHO Guideline. The positive results of both cytogenetic evaluation of $t(9 ; 22)$ and molecular study of BCR-ABL are required for the diagnosis. According to the WHO classification, CML patients 
Table 1 Patients characteristics

\begin{tabular}{lc}
\hline Patient Characteristic & $\mathbf{n}$ \\
\hline Sex & \\
Male & 43 \\
Female & 17 \\
Phase & \\
$\quad$ CML-CP & 38 \\
CML-AP & 9 \\
CML-BC & 13 \\
Treatment of CML-CP & \\
With imatinib & 31 \\
Without imatinib & 7
\end{tabular}

Abbreviations: AP: accelerated phase; BC: blast crisis;

$\mathrm{CP}$ : chronic phase;CML:Chronic Myelogeneous Leukemia.

were divided into three groups: chronic phase $(\mathrm{CP})$, accelerated phase (AP) and blast crisis (BC). In addition, 38 CML-CP patients were divided into two groups: 31 treated with imatinib,7 treated with hydroxycarbamide and IFN $\alpha$ (see Table 1). This study also includes 25 healthy donors. Mononuclear cells were obtained by BM aspiration after obtaining informed consent. The study was approved by the Sichuan University institution review board.

\section{RNA isolation}

Total RNA was extracted from mononuclear cells using an RNA extraction kit from Invitrogen according to the manufacturer's instruction(Carlsbad, CA, USA).RNA quality was determined by agarose gel electrophoresis and quantified spectroscopically $(260 \mathrm{~nm})$ using a Biophotometer (Eppendorf, Hamburg, Germany).

\section{Reverse-transcription PCR}

Complimentary DNA was synthesized from $2 \mu \mathrm{g}$ of total RNA from each samples using RNA PCR Kit (AMV) (Promega, Madison, WI). Commercially synthesized PCR primers were used to amplify specific Hh transcripts:

Shh(F:5'-CCTCGCTGCTGGTATGCTCGGGACT-3', R:5'-CTCTGAGTCATCAGCCTGTCCGCTC-3');Ptch1: (F:5'-GCACTACTTCAGAGACTGGCTTC-3', R:5'-AGA AAGGGAACTGGGCATACTC-3');Smo(F:5'-ACCCCG GGCTGCTGAGTGAGAAG-3', R:5'-TGGGCCCAGGC AGAGGAGACATC-3');Gli-1(F:5'-TCCTACCAGAGT CCCAAGTTTC-3', R:5'-CCAGAATAGCCACAAAGT CCAG-3'); $\beta$-Actin(F:5'-CCAAGGCCAACCGCGAGAA GATGAC-3', R:5'-AGGGTACATGGTGGTGCCGCCA GAC-3').

The predicted sizes of the PCR products were $262 \mathrm{bp}$ for Shh,395 bp for Ptch1,562 bp for Smo,391 bp for Gli-1 and 587 bp for $\beta$-Actin.PCR reaction mixtures contained $1 \mathrm{ul}$ cDNA,3 ul $\mathrm{Mgcl}_{2}(25 \mathrm{mM}), 4 \mathrm{ul} \mathrm{dNTP}(2.5 \mathrm{mM}), 10 \times \mathrm{PCR}$ Buffer 5 ul,0.5 umol of each primer and 1.25 units of heat-stable DNA polymerase(Takara, Biotech, Japan). Amplification programmes were applied for $\mathrm{Shh}(25$ cycles at $94^{\circ} \mathrm{C}, 65^{\circ} \mathrm{C}$ and $72^{\circ} \mathrm{C}, 45 \mathrm{~s}$ each), Ptch $1\left(28\right.$ cycles at $94^{\circ}$ $\left.\mathrm{C}, 30 \mathrm{sec} ; 60^{\circ} \mathrm{C}, 30 \mathrm{sec} ; 72^{\circ} \mathrm{C}, 45 \mathrm{~s}\right), \mathrm{Smo}\left(28\right.$ cycles at $94^{\circ} \mathrm{C}, 30$ sec; $\left.55^{\circ} \mathrm{C} 30 \mathrm{sec} ; 72^{\circ} \mathrm{C}, 45 \mathrm{~s}\right)$, Gli- $1\left(30\right.$ cycles at $94^{\circ} \mathrm{C}, 30 \mathrm{sec}$; $57^{\circ} \mathrm{C}, 30 \mathrm{sec} ; 72^{\circ} \mathrm{C}, 45 \mathrm{~s}$ ). Four independent PCR reactions were carried out with different numbers of PCR cycles thus ensuring that each PCR amplification was not reach the plateau phase. Subseqently, 5 ul PCR product was subjected to $1.5 \%$ agarose gel electrophoresis followed by ethidium bromide staining. The density of PCR products were measured by Bio-Rad gel imaging system(Bio-Rad, USA) of photographs of ethidium-bromide-stained agarose gels. The relative gene expression of Shh, Ptch1, Smo, Gli1 were determined by comparing the ratio of PCR products of the target cDNA segments and the $\beta$-Actin cDNA segment as a reference.

\section{Statistical analysis}

The data are presented as means \pm SEM. The differences between the mean values of two groups were evaluated by using the Student's t-test (unpaired comparison). For comparison of more than three groups, we used one-way analysis of variance (ANOVA) test followed by Tukey's multiple comparison. $\mathrm{P}$ values of $<0.05$ were considered statistically significant.

\section{Results}

Increased Hh target gene expression in CML

We examined expression of $\mathrm{Hh}$ and its receptors in CML and normal controls by semiquantitative PCR. Shh, Ptch1, Smo, Gli1 mRNA can be detected in both CML group and normal control group. We analyzed the relative expression levels of Shh, Ptch1, Smo, Gli1 mRNA in all groups, and the results indicated that Shh, Smo, Gli1 mRNA levels in CML group were significantly higher than those in control group $(\mathrm{p}<0.005)$. But there is no significant difference for the mRNA expression of Ptch1 between CML group and normal control group $(\mathrm{p}>0.05)$ (see Figure 1).

\section{Expression of $\mathrm{Hh}$ and its receptors in different phases of CML}

Further analysis of the data revealed an association of Hh signaling activation with progression of CML. We compared the transcript levels of $\mathrm{Hh}$ and its receptors in patients with CML in chronic phase, accelerated phase and blast crisis. The levels of Shh mRNA in patients of CML-CP were obviously lower than that of CML-AP or CML-BC( $<<0.05)$, but there were no significant differences between CML-AP group and CMLBC group. Our results also demonstrated elevated Smo expression in patients of CML-BC. The relative expression levels of Smo mRNA in CML-BC group were 


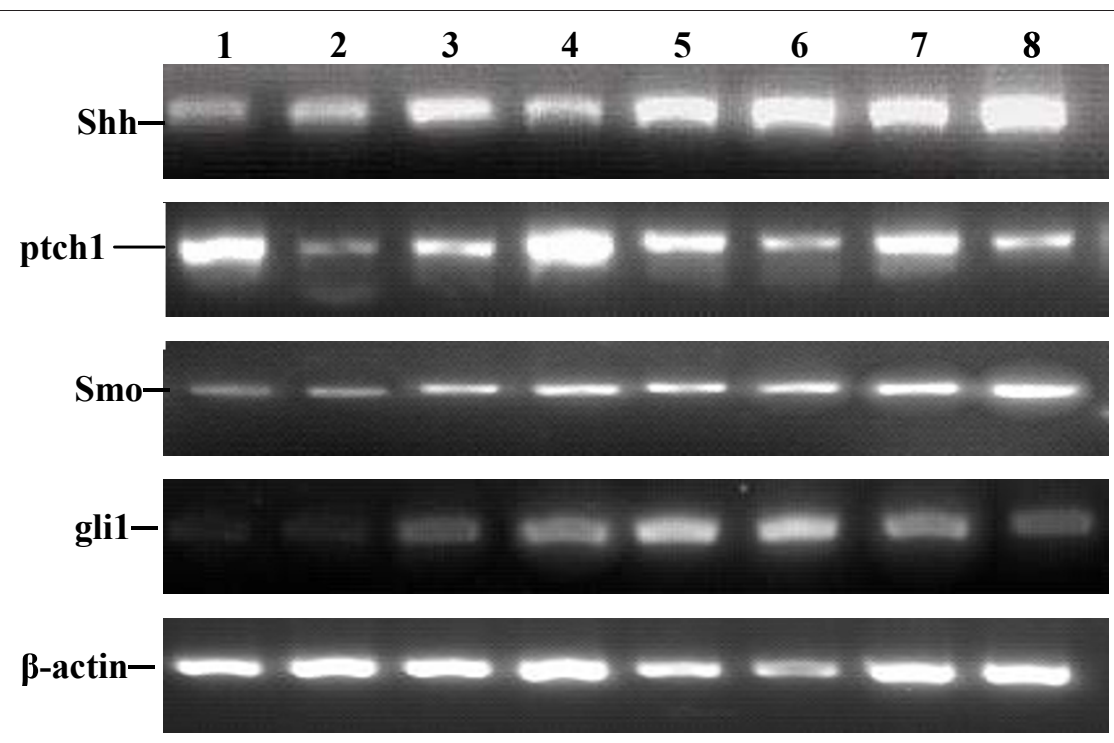

262bp

395bp

$562 \mathrm{bp}$

$391 b p$

$587 \mathrm{bp}$

Figure 1 Expression of $\mathrm{Hh}$ and its receptors in CML patients and normal control. Lane 1:normal control 1:Lane 2:normal control 2:Lane 3: CML-CP case 1:Lane 4:CML-CP case 2:Lane 5:CML-AP case 1:Lane 6:CML-AP case 2:Lane7:CML-BC case 1:Lane8: CML-BC case 2.

much higher than in CML-CP group, but no significant differences were found between CML-CP and CML-AP group, CML-AP and CML-BC group. Moreover, in most of the cases, increased levels of Shh were consistent with elevated levels of Smo expression. We also found high Gli1 and Ptch1 transcripts in patients of CML-BC and CML-AP compared with the CML-CP group, but there were no significant differences between these three groups $(\mathrm{p}>0.05)$ (see Figure 2$)$.
Expression of $\mathrm{Hh}$ and its receptors in CML-CP patients with IM administered or not

It is reported that expansion of BCR-ABL-positive leukemic stem cells and the maintenance of self-renewal properties in this population are dependent on intact and activated Hh signaling, therefore, it is intriguing to postulate that imatinib have no role on Hh pathway. To test this possibility, we analyzed the levels of Shh, Ptch1, Smo, and Gli1 expression in 38 CML-CP patients, with

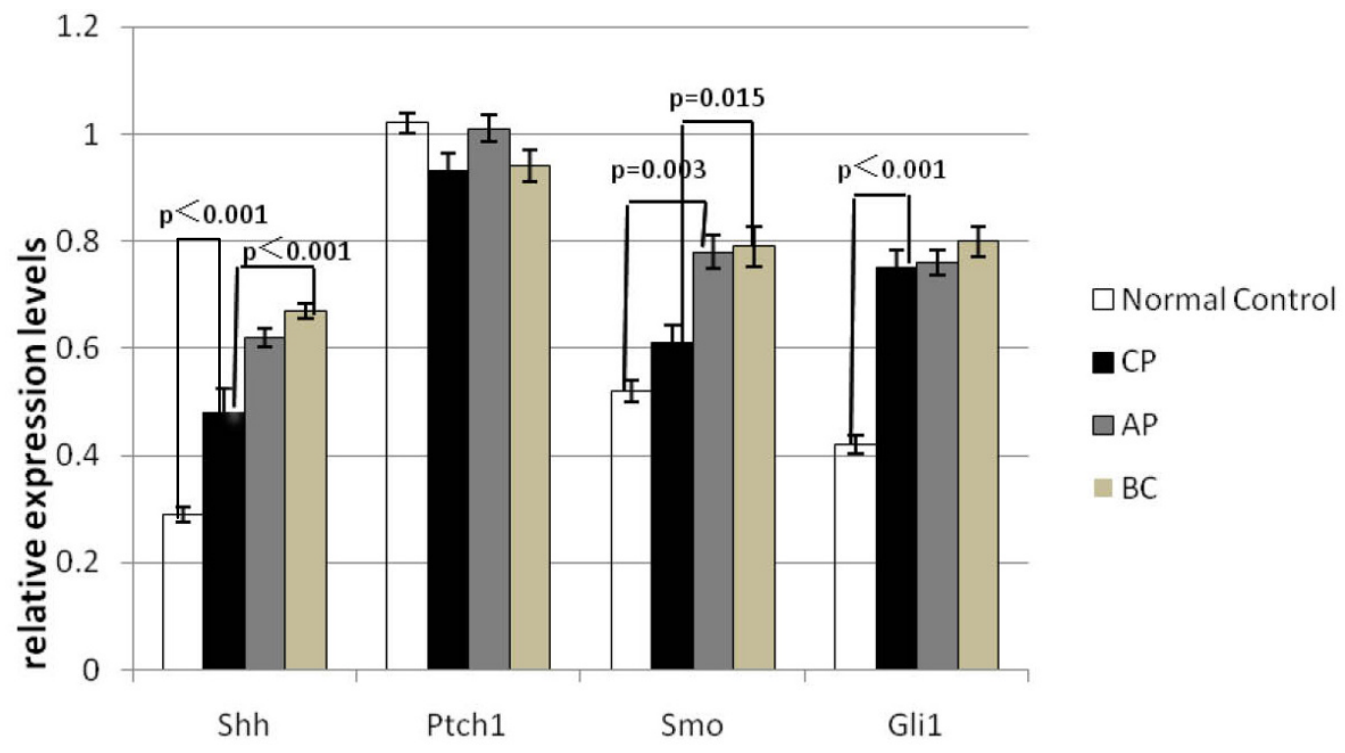

Figure $\mathbf{2}$ Comparison of $\mathrm{Hh}$ and its receptors expression between different groups 


\begin{tabular}{|c|c|c|c|}
\hline CML-CP & $\mathrm{n}$ & $\begin{array}{c}\text { Expression } \\
\text { level }\left({ }^{\circ} \mathrm{C} \pm \mathrm{S}\right)\end{array}$ & $P$ value \\
\hline \multicolumn{4}{|l|}{ Shh } \\
\hline Without Imatinib & 7 & $0.55 \pm 0.020$ & 0.24 \\
\hline With Imatinib & 31 & $0.46 \pm 0.017$ & \\
\hline \multicolumn{4}{|l|}{ Ptch1 } \\
\hline Without Imatinib & 7 & $1.21 \pm 0.031$ & 0.12 \\
\hline With Imatinib & 31 & $0.87 \pm 0.031$ & \\
\hline \multicolumn{4}{|l|}{ Smo } \\
\hline Without Imatinib & 7 & $0.66 \pm 0.020$ & 0.88 \\
\hline With Imatinib & 31 & $0.59 \pm 0.023$ & \\
\hline \multicolumn{4}{|l|}{ Gli1 } \\
\hline Without Imatinib & 7 & $0.83 \pm 0.042$ & 0.43 \\
\hline With Imatinib & 31 & $0.73 \pm 0.027$ & \\
\hline
\end{tabular}

31 patients treated with imatinib and another 7 patients treated with hydroxycarbamide and IFN $\alpha$. As expected, we found that there were no significant differences of Shh, Ptch1, Smo, Gli1 mRNA expression when comparing CML-CP patients with IM treated or not $(\mathrm{p}>0.05)$ (see Table 2).

\section{Discussion}

Hedgehog signaling pathway is important in the pathogenesis of several malignancies. Several mechanisms have been described that lead to the activation of the Hh signaling pathway in tumor cells, such as activating point mutations of Smo or inactivating point mutations in Ptch1 or SUFU [8-12]. Although inappropriate activation of the Hh signaling pathway has been shown in many cancers, the assessment of the contribution of $\mathrm{Hh}$ signaling pathway has not been thoroughly examined in hematologic malignancies. Given the parallels in Hh signaling between regulation of proliferation of primitive human hematopoietic cells and hematologic malignancies [13-15], we examined whether Hh signaling might also have a role in CML.

Here, with the use of semiquantitative PCR analysis, we showed that the Hh signaling components Shh, Ptch1, Smo and Gli1 were expressed in all CML patients that we screened. And the relative expression levels of Shh, Smo, and Gli1 mRNA in CML group were significantly higher than those in normal control group, suggesting that activation of the Hh pathway is quite common in CML. But the level of Ptch1 mRNA in CML and normal control group did not show significant difference. We repeated the amplification procedure several times, but there was still no difference found. The reason might be that the primary $\mathrm{CD} 34^{+}$leukemic cells have been not separated. Furthermore, we found elevated Shh, Ptch1, Smo, Gli1 transcripts in advanced stages of CML, especially the levels of Shh, Smo expression were significantly higher in blast crisis than that in chronic phase of CML. A significant correlation between increased expression of both Shh and Smo in patients of CML-BC would support the hypothesis that aberrant Hh signaling contributes to CML development or progression.

The outcome for CML patients has been dramatically improved with the use of tyrosine kinase inhibitors (TKIs), leading to response rates of greater than $95 \%$ [16]. Although it is very effective in treating chronic phase CML patients, imatinib will unlikely provide a cure to these patients. Several reports indicate that discontinuation of imatinib treatment even in patients who have already achieved molecular response induces a relapse of the disease [17], and therefore, patients are forced to undergo lifelong therapy. Further studies have demonstrated that imatinib effectively eradicates BcrAbl-positive progenitor cells but does not target BcrAbl-positive CD34+ LSCs [1,2], as there is evidence that Bcr-Abl-positive LSCs remain present in the patient's bone marrow even after years of therapy and can cause relapse of disease [18-20]. Our study indicated that imatinib treatment has no significant influence on the inhibition of Hedgehog pathway of CML-CP patients.

Although responses to interferon-alpha (IFN $\alpha$ ) are slower and less dramatic than those to imatinib, they can be durable even after discontinuation of the drug [21-23]. Unlike imatinib, the specific mechanisms responsible for IFN's clinical activity in CML are unknown. Previous report indicated that IFNa inhibits Mek phosphorylation in hedgehog pathway activated basal cell carcinoma (BCC) cells [24]. At the current time, there is still much to learn about the role of $\mathrm{Hh}$ signaling pathway in the development and progression of CML, and further studies will be required to understand the biological function(s) of IFNa in the Hh pathway.

In conclusion, we confirmed variable abnormalities of Hedgehog pathway activation in CML cases involved in this study, raising a possibility that combinations of $\mathrm{ABL}$ and Hh inhibitors might offer a new treatment strategy in CML and might help to effectively cure this disease.

\section{Abbreviations}

AP: accelerated phase; BC: blast crisis; CML: Chronic Myelogeneous Leukemia; CP: chronic phase; Hh: Hedgehog; HSC: hematopoietic stem cell; IM: imatinib; LSCs: leukemia stem cells; PCR: polymerase chain reaction; Ptch: Patched; Shh: Sonic hedgehog; Smo: Smoothened.

\section{Authors' contributions}

$H Z, B L, T L$ and $W M$ designed the study, BL and $C Z$ carried out $P C R, H Z$, Bing Long drafted the manuscript and performed the statistical analysis. All authors read and approved the final manuscript.

\section{Competing interests}

The authors declare that they have no competing interests. 
Received: 24 October 2010 Accepted: 16 January 2011

Published: 16 January 2011

\section{References}

1. Graham SM, Jorgensen HG, Allan E, Pearson C, Alcorn MJ, Richmond L, Holyoake TL: Primitive, quiescent, Philadelphia-positive stem cells from patients with chronic myeloid leukemia are insensitive to STI571 in vitro. Blood 2002, 99(1):319-325.

2. Jorgensen $H G$, Allan EK, Jordanides NE, Mountford JC, Holyoake TL: Nilotinib exerts equipotent antiproliferative effects to imatinib and does not induce apoptosis in CD34+ CML cells. Blood 2007, 109(9):4016-4019.

3. Zhao C, Chen A, Jamieson CH, Fereshteh M, Abrahamsson A, Blum J, Kwon HY, Kim J, Chute JP, Rizzieri D, Munchhof M, VanArsdale T, Beachy PA, Reya T: Hedgehog signaling is essential for maintenance of cancer stem cells in myeloid leukemia. Nature 2009, 458(7239):776-779.

4. Dierks C, Beigi R, Guo GR, Zirlik K, Stegert MR, Manley P, Trussell C, SchmittGraeff $A$, Landwerlin K, Veelken $H$, Warmuth M: Expansion of BCR-ABL positive leukemic stem cells is dependent on Hedgehog pathway activation. Cancer cell 2008, 14(3):238-249.

5. Varjosalo M, Taipale J: Hedgehog signaling. J Cell Sci 2007, 120:3-6.

6. Huangfu D, Anderson KV: Signaling from Smo to $\mathrm{Ci} / \mathrm{Gli}$ : conservation and divergence of Hedgehog pathways from Drosophila to vertebrates. Development 2006, 133(1):3-14.

7. Molly DS, Weng L, Xin SJ, Du W: Hedgehog regulates cell growth and proliferation by inducing Cyclin D and Cyclin E. Nature 2002, 417(6886):299-304

8. Johnson RL, Rothman AL, Xie J, Goodrich LV, Bare JW, Bonifas JM, Quinn AG, Myers RM, Cox DR, Epstein EH Jr, Scott MP: Human homolog of patched, a candidate gene for the basal cell nevus syndrome. Science 1996, 272(5268):1668-1671.

9. Hahn H, Wicking C, Zaphiropoulous PG, Gailani MR, Shanley S, Chidambaram A, Vorechovsky I, Holmberg E, Unden AB, Gillies S, Negus K, Smyth I, Pressman C, Leffell DJ, Gerrard B, Goldstein AM, Dean M, Toftgard R, Chenevix-Trench G, Wainwright B, Bale AE: Mutations of the human homolog of Drosophila patched in the nevoid basal cell carcinoma syndrome. Cell 1996, 85(6):841-851.

10. Xie JW, Murone M, Luoh SM, Ryan A, Gu Q, Zhang C, Bonifas JM, Lam CW, Hynes M, Goddard A, Rosenthal A, Epstein EH Jr, de Sauvage FJ: Activating smoothened mutations in sporadic basal-cell carcinoma. Nature 1998, 391(1):90-92.

11. Xie JW, Johnson $\mathrm{RL}$, Zhang $\mathrm{XL}$, Bare JW, Waldman FM, Cogen $\mathrm{PH}$, Menon AG, Warren RS, Chen LC, Scott MP, Epstein EH Jr: Mutations of the patched gene in several types of sporadic extracutaneous tumors. Cancer Res 1997, 57(12):2369-2372.

12. Karhadkar SS, Hallahan AR, Pritchard Jl, Eberhart CG, Watkins DN, Chen JK, Cooper MK, Taipale J, Olson JM, Beachy PA: Medulloblastoma growth inhibition by hedgehog pathway blockade. Science 2002, 297(5586):1559-1561.

13. Dierks C, Grbic J, Zirlik K, Beigi R, Englund NP, Guo GR, Veelken H, Engelhardt M, Mertelsmann R, Kelleher JF, Schultz P, Warmuth M: Essential role of stromally induced hedgehog signaling in B-cell malignancies. Nature Medicin 2007, 13(8):944-951.

14. Bai LY, Chiu CF, Lin CW, Hsu NY, Lin CL, Lo WJ, Kao MC: Differential expression of Sonic hedgehog and Gli1 in hematological malignancies. Leukemia 2008, 22(1):226-228.

15. Peacock CD, Wang QJ, Gesell GS, Corcoran-Schwartz IM, Jones E, Kim J, Devereux WL, Rhodes JT, Huff CA, Beachy PA, Watkins DN, Matsui W: Hedgehog signaling maintains a tumor stem cell compartment in multiple myeloma. PNAS 2007, 104(10):4048-4053.

16. Hochhaus A, O'Brien SG, Guilhot F, Druker BJ, Branford S, Foroni L, Goldman JM, Müller MC, Radich JP, Rudoltz M, Mone M, Gathmann I, Hughes TP, Larson RA: IRIS Investigators. Six-year follow-up of patients receiving imatinib for the first-line treatment of chronic myeloid leukemia IRIS 6-year follow-up. Leukemia 2009, 23(6):1054-1061.

17. Merante S, Oriandi E, Bernasconi P, Calatroni S, Boni M, Lazzarino M: Outcome of four patients with chronic myeloid leukemia after imatinb mesylate discontinuation. Haematologica 2005, 90(7):979-981.

18. Chu S, Xu H, Shah NP, Snyder DS, Forman SJ, Sawyers CL, Bhatia R: Detection of BCR-ABL kinase mutations in CD34+ cells from chronic myelogenous leukemia patients in complete cytogenetic remission on imatinib mesylate treatment. Blood 2005, 105(5):2093-2098.
19. Barnes DJ, Melo JV: Primitive, quiescent and difficult to kill: the role of non-proliferating stem cells in chronic myeloid leukemia. Cell Cycle 2006, 5(24):2862-2866

20. Hu Y, Swerdlow S, Duffy TM, Weinmann R, Lee FY, Li S: Targeting multiple kinase pathways in leukemic progenitors and stem cells is essential for improved treatment of $\mathrm{Ph}+$ leukemia in mice. PNAS 2006, 103(45):16870-16875

21. Pierce $A$, Smith $D L$, Jakobsen $L V$, Whetton $A D$, Spooncer $E$ : The specific enhancement of interferon alpha induced growth inhibition by $B C R / A B L$ only occurs in multipotent cells. Hematology Journal 2001, 2(4):257-264.

22. The Italian Cooperative Study Group on Chronic Myeloid Leukemia: Interferon Alfa-2a as compared with conventional chemotherapy for the treatment of chronic myeloid leukemia. The New England Journal of Medicine 1994, 330(12):820-825

23. Bonifazi F, de Vivo A, Rosti G, Guilhot F, Guilhot J, Trabacchi E, Hehlmann R, Hochhaus A, Shepherd PC, Steegmann JL, Kluin-Nelemans HC, Thaler J, Simonsson B, Louwagie A, Reiffers J, Mahon FX, Montefusco E, Alimena G, Hasford J, Richards S, Saglio G, Testoni N, Martinelli G, Tura S, Baccarani M, Europena Study Group on Interferon in Chronic Myeloid Leukemia; Italian Cooperative Study Group on CML; France Intergroup of CML; German CML Study Group; UK Medical Research Council Working Party on CML, et al: Chronic myeloid leukemia and interferon -alpha: a study of complete cytogenetic esponders. Blood 2001, 98(10):3074-3081.

24. Cheng XL, Sumin C, Nonggaao H, Li C, Chi S, He N, Zhang X, Guicherit O, Wagner R, Tyring S, Xie J: IFNa induces Fas expression and apoptosis in hedgehog pathway activated BCC cells through inhibiting Ras-Erk signaling. Oncogene 2004, 23(8):1608-1617.

\section{doi:10.1186/1756-9966-30-8}

Cite this article as: Long et al:: Activation of the hedgehog pathway in chronic myelogeneous leukemia patients. Journal of Experimental \& Clinical Cancer Research 2011 30:8

\section{Submit your next manuscript to BioMed Central and take full advantage of:}

- Convenient online submission

- Thorough peer review

- No space constraints or color figure charges

- Immediate publication on acceptance

- Inclusion in PubMed, CAS, Scopus and Google Scholar

- Research which is freely available for redistribution

Submit your manuscript at www.biomedcentral.com/submit
C Biomed Central 